\title{
What Does an Engineer Do? Conceptual Changes and Effects of Fellow Engagement on Middle School Students Involved in a GK-12 Program
}

\author{
Vincent R. Genareo ${ }^{\mathrm{a}}$, Mari Kemis ${ }^{\mathrm{b}}$, D. Raj Raman ${ }^{\mathrm{b}}$ \\ ${ }^{a}$ Salisbury University, USA; ${ }^{b}$ Iowa State University, USA
}

\begin{abstract}
This study investigates students' conceptions of engineering at the beginning and end of their involvement in a National Science Foundation funded Graduate STEM Fellows in K-12 Education (GK-12) program. It examines whether students involved in the program exhibited greater conceptions of engineering from beginning to end, whether differences exist among males and females, and if students' engagement and satisfaction with their Fellows affects growth in conceptions of engineering. Pre-survey and post-survey data were collected annually over four years from 1,522 participants in grades 7 and 8 who had a GK-12 Fellow. Statistical analyses indicated students gained significantly in their conceptions of engineering during a year of GK-12 involvement. Those with a second year benefitted more, and the initial conception of engineering gap that occurred between males and females was closed by the end of students' involvement in GK-12. The greater the degree of student engagement and satisfaction with their GK-12 Fellows, the more accurate were their conceptions of engineering. This study suggests STEM-focused partnership programs may positively affect students' career conceptions, and there is value in value placing resident scientists who can facilitate student engagement in classrooms. Recommendations to program coordinators are provided.
\end{abstract}

Keywords: STEM partnerships, middle school, conceptions of engineering

\section{Introduction}

One In 1999, the National Science Foundation (NSF) launched the Graduate STEM Fellows in K-12 in Education (GK-12) program that paired Ph.D.-level graduate students (Fellows) with K-12 classroom teachers. Although the focus of these programs varied by institution, they generally followed one of two models (Mitchell et al., 2003). The "exposition model" provided Fellows with opportunities in schools to present to students and teachers in a limited capacity, while the "classroom immersion model" paired Fellows with one or more K-12 teachers in the classroom throughout a school year. Most GK-12 programs used the latter approach, and it was the model employed for this study.

Multiple investigators demonstrated the validity of using an analysis of drawing and writing samples to evaluate student conceptions of engineering (Capobianco, Diefes-Dux, Mena, \& Weller, 2011; Knight \& Cunningham, 2004). Some studies have focused on the impact of GK-12 programs (in particular) on students' perceptions of and attitudes toward engineering, finding students make gains in their conceptions of engineering, or develop more positive attitudes about engineering disciplines, as a result of having a scientist in their classroom (Lyons, 2011; Thompson \& Lyons, 2008). However, little research has examined gender differences in gains in conceptions of engineering, and no research has examined the relationships between student engagement and satisfaction with their GK-12 Fellows and increases in conceptions of engineering.

\footnotetext{
${ }^{1}$ Corresponding Author. Salisbury University, 1101 Camden Avenue, CH 281D Salisbury, MD 21801 Email: vrgenareo@salisbury.edu
} 


\section{Literature Review}

This research is grounded in the conceptual change model as proposed by Vosniadou (1994). This conceptual change model examines the nature of scientific conceptual change in children. In Vosniadou's model, students' concept acquisition are best supported when they actively engage in their learning, ask and answer questions, and are involved in a dialogue with teachers (Vosniadou, Ioannides, Dimitrakopoulou, \& Papademetriou, 2001). Students create mental models that allow them to understand and explain complex processes and theories. Students may change their conceptual understanding either through enrichment of existing conceptual models (adding to what they already know) or through revision of their conceptual models (changing what they believe). Inconsistencies in students' presuppositions, which underpin their mental models, create misconceptions. Misconceptions may be difficult to overcome, and often take active teaching processes to help students engage with material, question their presuppositions, and revise their conceptual models. Simply, conceptual revisions can occur through careful structuring of students' experiences (Vosniadou, 2007).

Numerous studies have examined students' conceptions and misconceptions of engineering. Previous research confirmed that elementary and middle school students hold misconceptions about the engineering field (Hammack \& High, 2014). Many of these students believe engineers perform mechanical work, fix vehicles, or drive trains (Fralick, Kearn, Thompson, \& Lyons, 2009; Cunningham, Lachapelle, \& Lindgren-Streicher, 2005). Typically, these studies use the Draw An Engineer Test (DAET), allowing students to draw and briefly explain the job of an engineer (Yap, Ebert, \& Lyons, 2003; Knight \& Cunningham, 2004).

Students in middle school begin to develop potential career aspirations, and stereotypes or misconceptions about the science fields can potentially cause students to avoid pursuing these careers (McDuffie, 2001). Studies of conceptions of engineering found that elementary and middle school students believe science and engineering are largely male-oriented fields (Fralick et al., 2009; Capobianco et al., 2011). The generally masculine conceptions of engineering can influence females' academic performance and career selection in those areas (Kelley \& Bryan, 2018). Students are more likely to select occupations when they accurately understand the field and have the self-confidence and self-efficacy to believe they can be successful (Komarraju, Swanson, \& Nadler, 2014).

To help develop middle school students' interest and confidence in engineering, most teachers need professional development to improve their pedagogical content knowledge and inquiry-based instructional strategies, and universities and engineering experts should provide outreach to schools to provide authentic and meaningful science, technology, engineering, and mathematics (STEM) experiences (Page, Lewis, Autenrieth, \& Butler-Purry, 2013; Rockland, Bloom, Carpinelli, Burr-Alexander, Hirsch, \& Kimmell, 2010). Unfortunately, Cantrell and Robinson (2002) found middle school and secondary science textbooks have historically provided classroom teachers with ineffective engineering activities and often fail to make concrete connections to math and science content. Although the GK-12 program had been shown to be a successful model for increasing student awareness of engineering fields (Lyons, 2011) and interest in engineering careers (DeGrazia, Sullivan, Carlson, \& Carlson, 2001), recent research called into question the effectiveness of the GK-12 program's longterm impact on students' interest and confidence in STEM careers. Genareo, Mitchell, Geisinger, and Kemis (2016) found that students lost interest and confidence in all four STEM areas between their middle school GK-12 involvement and the end of high school.

There is also a push to attract more students in STEM fields, particularly minority students and females (National Academy of Engineering, 2008). As of 2014, females accounted for only 15.2\% of tenured and tenuretrack faculty, and African Americans receiving a bachelor's degree in engineering had been on a consistently downward trend since 2005 (Yoder, 2014). Two of the goals of the GK-12 program were to "connect elementary and secondary learning to the habits and skills required for future study in STEM disciplines [and] provide role models for future STEM professionals" (Mitchell et al., 2003, p. 4). This study examined the GK-12 program's success in changing students' conceptions of engineering, and potential reasons for variations. 


\section{Significance of the Study}

The American public has a poor understanding of what engineers do (Davis \& Gibbons, 2002), and many teachers have even developed misconceptions about the engineering field (Cunningham et al., 2005). Some students may feel they are not smart enough to be engineers, or see it as an isolated and sedentary lifestyle that does not appeal to them (National Academy of Engineering, 2008). Misconceptions about engineering careers may contribute to fewer females in engineering fields (Tonso, 2006). Even as the number of female engineering students has increased over the last decade, as of 2015, woman accounted for only $21 \%$ of bachelor's degrees, $23 \%$ of master's degrees, and 25\% of doctoral degrees in engineering (Banerjee, 2015).

With an inadequate understanding of engineering, students are unlikely to select an engineering career (Hirsch, Carpinelli, Kimmell, Rockland, \& Bloom, 2007). Research in closely related fields, such as science, found that classroom interventions addressing students' misconceptions of scientists could help clarify their ideas about science careers (Finson, 2002). In relation, it is important to understand what beliefs students have developed about the engineering profession. While conceptions of engineering may be only one factor in these students' career decision-making, there is evidence that students are more likely to choose careers they understand, and in which they have role models (Lent, Brown, \& Hackett, 2002).

Middle school is a critical period for students in developing their interests in STEM fields, and it is vital that students are exposed to and develop STEM interests prior to high school (Mohr-Schroeder et al, 2014; Tafoya, Nguyen, Skokan, \& Moskal, 2005). Therefore, to add to existing literature on students' conceptions of engineering (Fralick et al., 2009), and to address the call for research of middle school intervention programs on student STEM career perceptions (Knezek, Christensen, Tyler-Wood, \& Periathiruvadi, 2013), this study examines: (1) magnitude and types of change in conceptions of engineering that occur as a result of middle school students' involvement in a school-university STEM partnership, specifically, their long-term exposure to a Fellow, (2) differences in gains between males and females, and (3) the generally unexplored research into levels of students' engagement and satisfaction with their Fellows and its correlation to gains in conceptions of engineering.

In this study, we examined middle school students' conceptions of engineering using pre-survey and post-survey data administered to all students in classrooms with a GK-12 Fellow. Students completed a presurvey within one to two weeks of the beginning of the school year and then a post-survey during the last month of the school year. Data were collected during four academic years. The findings describe students' gains in their conceptions of engineering; differences in gains between male and female students; gains of students who were in the program for a second year; and how their levels of engagement and satisfaction contribute to their gains in conceptions of engineering. Recommendations for program coordinators and researchers are then offered to aid in developing programs that may contribute to even greater student understanding of engineers and engineering.

\section{Research Questions}

Three research questions guided this study: (1) Do students involved in a GK-12 program develop significant changes in their conceptions of engineering? (2) Do males and females have different gains in their conceptions of engineering? (3) Does a higher level of student engagement and satisfaction with the GK-12 Fellow affect their change in conceptions of engineering?

\section{GK-12 Program Description}

The GK-12 program in this study was a five-year joint partnership between a university, a public school district, and the National Science Foundation (Award \# DGE - 1007911), using a classroom immersion model. Prior to the school year, the Fellows received 50 hours of professional development in pedagogy, realities of working in a middle school classroom, how to use technology in the classroom, and strategies for communicating science concepts to middle school students. During the school year, the Fellows and teachers worked together to prepare lessons and teaching activities. The Fellows were in the classroom one day a week, typically employing inquiry-based instructional methods. The objectives of the program were to: 1) provide 
Fellows with a graduate experience that prepared them for interdisciplinary research; 2) to train Fellows to become outstanding teachers and better communicators; 3 ) to provide professional development opportunities for middle school educators; and 4) to engage middle school students in scientifically-oriented questions and problem-based learning, intending to result in increased student interest in STEM fields.

The GK-12 Fellows were Ph.D. students in a variety of science programs at a large, Midwestern university. They sought advanced degrees in subjects including Agronomy; Biophysics and Molecular Biology; Chemical and Biological Engineering; Chemistry; Ecology, Evolution, and Organismal Biology; Materials and Science Engineering; Electrical and Computer Engineering; Genetics, Development, and Cell Biology; Natural Resource and Ecology Management; and Organic Chemistry. Six Fellows were selected during Year 1, nine during Year 2, 10 during Year 3, and nine during Year 4. Nine Fellows remained in the GK-12 program for two years. Table 1 lists the number, the program of study, gender, and racial/ethnic background of the Fellows during each of the four program years.

Table 1.

Fellow Demographics by Program Year

\begin{tabular}{cccccccl}
\hline $\begin{array}{c}\text { Program } \\
\text { Year }\end{array}$ & $\begin{array}{c}\text { New } \\
\text { Fellows } \\
(n)\end{array}$ & $\begin{array}{c}\text { Returning } \\
\text { Fellows } \\
(n)\end{array}$ & $\begin{array}{c}\text { Total } \\
\text { Fellows } \\
(N)\end{array}$ & $\begin{array}{c}\text { Program of } \\
\text { Study: Engi- } \\
\text { neering }(n)\end{array}$ & $\begin{array}{c}\text { Program of } \\
\text { Study: } \\
\text { Other Science } \\
(n)\end{array}$ & $\begin{array}{c}\text { Fellow } \\
\text { Gender }\end{array}$ & $\begin{array}{l}\text { Fellows' Racial/Ethnic } \\
\text { Background }\end{array}$ \\
\hline 1 & 6 & - & 6 & 0 & 6 & $3 \mathrm{~F}, 3 \mathrm{M}$ & $\begin{array}{l}5 \text { Caucasian, } \\
1 \text { African American } \\
2\end{array}$ \\
3 & 5 & 2 & 9 & 0 & 9 & $2 \mathrm{~F}, 7 \mathrm{M}$ & 8 Caucasian, \\
1 African American \\
4
\end{tabular}

\section{GK-12 Classroom Activities and Pedagogy}

In the classrooms, the Fellows worked with their partner classroom teachers to design engaging curriculum for the middle school students. Results of evaluation reports (collected annually by our research institute through surveys and focus groups with all participating Fellows and teachers) indicate that much of the teaching was grounded in student inquiry and project-based learning (both of which were taught to Fellows during their professional development prior to the school year). Students engaged in activities such as: flight simulators, chromatography labs, DNA extraction, and metabolism measurement of snakes. A small selection of project examples included creating: musical instruments, biodiesel, computer-coded applications, soap, robots, and genetically-modified plants. They engaged in measuring energy consumption of electronic products, designed Rube Goldberg machines to understand energy transfer, and built audio speakers. In reviewing their learning activities, it is difficult in most cases to determine whether these activities fall into categories of science or engineering. One engineering Fellow, for example, worked with the students to learn about viscoelastic materials (his dissertation research topic) to understand how forces affect polymers differently than other materials. Many such activities included concepts often considered elements of both engineering and science.

\section{Methodology}

\section{Participants}

Schools. Students in six schools participated in this study. All six schools were located in a large, urban school district, with a community population of approximately 200,000 , and served students in grades six through eight. They all had a generally diverse student body. Table 2 lists school demographic information, including enrollment, percentage of free/reduced lunch eligible students, and percentage of students of diverse backgrounds. 
Table 2.

Participating School Demographics

\begin{tabular}{|c|c|c|c|}
\hline School & $\begin{array}{l}\text { Approximate Enroll- } \\
\text { ment }\end{array}$ & Free/Reduced Lunch Eligible (\%) & $\begin{array}{c}\text { Students of Diverse Back- } \\
\text { grounds (\%) }\end{array}$ \\
\hline A & 750 & 58.0 & 36.1 \\
\hline B & 650 & 72.9 & 51.4 \\
\hline $\mathrm{C}$ & 720 & 76.2 & 63.8 \\
\hline $\mathrm{D}$ & 700 & 93.9 & 74.2 \\
\hline $\mathrm{E}$ & 490 & 85.2 & 44.3 \\
\hline $\mathrm{F}$ & 630 & 97.6 & 85.7 \\
\hline
\end{tabular}

Students. A total of 1,522 students in seventh and eighth grade participated in this study. Fifty-one percent of participating students were female. Approximately $51 \%$ were in seventh grade and $49 \%$ were in eight grade, and about $49 \%$ were students of diverse racial or ethnic backgrounds. Table 3 lists the student participant demographic information.

Table 3.

Student Demographic Information by Program Year

\begin{tabular}{cccccccc}
\hline Year & $\begin{array}{c}\text { Schools } \\
\text { (from Table 1) }\end{array}$ & $\begin{array}{c}\text { Grade 7 } \\
(n)\end{array}$ & $\begin{array}{c}\text { Grade 8 } \\
(n)\end{array}$ & $\begin{array}{c}\text { Year Total } \\
(n)\end{array}$ & $\begin{array}{c}\text { Female } \\
\text { Students } \\
(n)\end{array}$ & $\begin{array}{c}\text { Male Stu- } \\
\text { dents }(n)\end{array}$ & $\begin{array}{c}\text { Students of } \\
\text { Diverse Back- } \\
\text { grounds }(n)\end{array}$ \\
\hline 1 & A, B, C, D, F & 127 & 194 & 321 & 153 & 167 & 148 \\
2 & A, B, C, D, E, F & 210 & 178 & 388 & 201 & 183 & 189 \\
3 & A, B, C, D, E & 237 & 194 & 431 & 223 & 200 & 213 \\
4 & A, B, C, D, E & 203 & 179 & 382 & 194 & 183 & 190 \\
Total & & 777 & 745 & 1522 & 771 & 733 & 740 \\
\hline
\end{tabular}

Note: 18 students did not provide their gender.

\section{Survey}

Students with a GK-12 Fellow completed a pre-survey in August and a post-survey in April. These surveys measured students' attitudes, perceptions, and confidence in STEM areas, including engineering. At both administrations, an open-ended item on the survey asked them to respond to the question, "What does an engineer do?" To determine the level of students' conceptions of engineering, a coding system was developed to quantify conceptual levels of students' responses. Additionally, five survey items asked students to rate, on a Likert-type scale, their level of agreement with: (1) I like talking to our Fellow; (2) Our Fellow makes learning more interesting; (3) I like having a Fellow in our classroom; (4) I am more interested in studying science because we had a Fellow in our classroom; and (5) Our Fellow helps us understand what we're learning in class. The Fellow administered the survey during regular class time.

\section{Coding Rubric Development}

Traditionally, conceptions of engineering have been measured using the Draw-an-Engineer Test (DAET) (Yap, Ebert, \& Lyons, 2003), which is a modified version of the Draw-a-Scientist Test (Chambers, 1983). Students' drawings and small writing samples are coded to determine what students believed engineers look like and do. Typically, responses are presented descriptively and without levels of greater understanding, although it is generally understood that a "low level" of conception involves beliefs that engineers build things, fix things, or drive trains or cars (Knight \& Cunningham, 2004). Updated scoring guidelines for the DAET allow for conceptual levels (from 0-3) that indicate levels of conceptions of engineering (Thompson \& Lyons, 2008). Using these scoring levels as a guide, the coding rubric, with codes from $0-4$, was developed and further refined during the coding process (see Appendix A for the coding rubric). 
The rubric was anchored by codes of $0-2$, indicating misconceptions or elementary understanding of engineers, and 3-4 that indicated a more sophisticated conceptions of engineering. Lower coded responses (coded 0-2) indicated misconceptions or elementary understanding of engineers. For example, if a student wrote a response with no content (e.g." "I don't know), the response was coded as a zero. If a student's response displayed a common misconception (e.g., "Engineers work in hospitals taking care of the sick"), or equated an engineer to an automobile mechanic or train operator, a common misconception among young people (Knight \& Cunningham, 2004), the response was coded as a one.

Responses coded as a two included an example of work engineers perform or the items they work with, referred to as engineering products (Oware, Capobianco, \& Diefes-Dux, 2007). If students provided one engineering product (e.g., "Engineers make bridges"), wrote that engineers build or fix things, or provided vague responses (e.g., "Math and science"), their response was coded as a two. These responses are higher-level, but if students believe engineers only build or fix things, it can be a sign of an incomplete understanding of the career, or potential misconceptions (Fralick et al., 2009).

Higher coded responses (coded 3-4) indicated a more sophisticated conceptions of engineering. Items coded as a three represented more complex understanding of engineers, because they either offered multiple engineering products (e.g." "They can make things like computers, bridges, etc.") or included a function of engineering (e.g., "managing, teaching, testing") that is not typically represented in conceptions of engineering research (Eide, Jenison, Northup, \& Mickelson, 2012). The highest level of conceptions of engineering was coded as a four. These responses could have included multiple functions of engineers (e.g., "Engineers design and invent..."), engineering as a means of social or organizational improvement (e.g., "Engineers help society by..."), or combined code levels two and three in some fashion (e.g., "Use science and math to design medical instruments").

Rubric validity. The rubric was developed in collaboration between staff in a research institute with expertise in assessment and a full professor of engineering. The rubric was created through alignment of elements in undergraduate engineering textbooks, supporting its face validity. To determine content validity, the rubric was sent to two university assistant professors in engineering fields and one assessment specialist, who examined the content of each rubric level. They were supplied with a copy of the rubric, and, using the Lawshe approach (Gilbert \& Prion, 2016), were asked to rate whether the content of each coding level represented content that was Essential, Useful but Not Necessary, or Not Essential to measuring students' conceptions of engineering. The Content Validity Index (CVI) value for the rubric was .99, meaning the three experts rated each of the rubric items as being essential to measuring the intended content of the rubric.

Rubric coding reliability. One researcher used the rubric to code all responses for conceptions of engineering. A second researcher coded a reduced sample of student responses. Cohen's Kappa determined if there was inter-rater reliability between the two scorers' codes (Table 4). Percentage of agreement was also computed to report the percentage of matched coding. An agreement of $85 \%$ is generally acceptable (Leedy, 1997).

Table 4.

Coding Reliability

\begin{tabular}{lcccccc}
\hline & $\begin{array}{c}\text { Coded Cases for } \\
\text { Reliability }(n)\end{array}$ & $\begin{array}{c}\% \text { of Total } \\
\text { Cases }\end{array}$ & $\begin{array}{c}\text { \% Coder } \\
\text { Agreement }\end{array}$ & $k$ & $\begin{array}{l}\text { Agreement } \\
\text { Classification }^{\mathrm{a}}\end{array}$ & $p$ \\
\hline $\begin{array}{l}\text { Engineer Concep- } \\
\text { tion }\end{array}$ & & & & & & \\
pre & 1109 & 72.9 & 88.3 & .832 & $\begin{array}{l}\text { Almost per- } \\
\text { fect }\end{array}$ & $<.0005$ \\
post & 1014 & 66.6 & 86.8 & .712 & Substantial & $<.0005$ \\
\hline
\end{tabular}

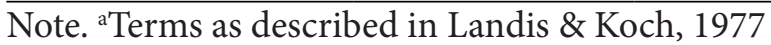


After examining scoring reliability and agreement, coding differences were discussed, agreed on, and recoded if necessary. Finally, the coding rubric was refined to better clarify the categories.

Item factor analysis. A factor analysis, using a Varimax rotation, tested the factorability of the five, Likert-type survey items. The completed student responses were tested with a Principle Components Analysis to analyze item variance, resulting in a Kaiser-Meyer-Olkin measure sampling adequacy of .885, $\mathrm{p}<.001$, well above traditional recommended value of .60. This confirmed that each item shared common variance with the other items, or that all items factored into a common construct, which was termed student engagement and satisfaction.

\section{Data Analysis}

A paired-samples t-test determined if gains in conceptions of engineering were significant for all years combined. An independent samples t-test examined significance in gains between males and females. Results were reported as means of beginning and end conceptions of engineering, gains, and potential significance for all responses overall, as well as for males and females. For students involved in the GK-12 program a second year, a repeated measures Analysis of Variance (ANOVA) provided significance of conception of engineer mean gains from the beginning of the first year to the end of the first and second years. Matched student responses were selected to demonstrate the types of gains students made in their responses at each growth level $(0-4)$. By recoding variables by student response levels, independent samples t-tests showed the significance of gains students made in their conceptions of engineering at each level of agreement (strongly disagree to strongly agree) on five survey items representing students' levels of engagement and satisfaction with their fellows.

\section{Results}

The following section provides the results of the investigation of the study's three research questions. The gains in conceptions of engineering by student gender and overall student sample are presented. Next, students' gains by self-reported engagement and satisfaction with the Fellow are reported. Finally, results of overall growth, and by gender, for students who had a second year of GK-12 involvement are presented.

\section{Changes in Conceptions of Engineering}

During the four project years, the total gains in students' conceptions of engineering as measured by the rubric (0-4) prior to their involvement in the GK-12 program to the end of their academic year of involvement were significant, $\mathrm{t}(1521)=12.28, \mathrm{p}<.001$ (Table 5). Students exhibited a mean gain of .43 . Additional analysis by each project year had similar results (not tabled). Overall, students involved in the GK-12 program made significant gains in their conceptions of engineering after one year of participation, progressing from a level of misconceptions or simplistic understanding $(\mathrm{m}=1.84)$ to a level of understanding the varied or multiple roles of engineers $(m=2.27)$. It is important to note that analyses were run by the Fellows' program (i.e., differences in student gains whether they had Fellows who were scientists and engineers), and no statistical differences occurred because of Fellows' program.

Table 5.

Gains in Conceptions of Engineering

\begin{tabular}{|c|c|c|c|c|c|c|c|c|}
\hline & \multicolumn{3}{|c|}{ Prior to Program } & \multicolumn{3}{|c|}{ After Program } & \multirow[b]{2}{*}{ Mean Gain } & \multirow[b]{2}{*}{$t$} \\
\hline & $n$ & $M$ & $S D$ & $n$ & $M$ & $S D$ & & \\
\hline Total & 1522 & 1.84 & 1.11 & 1522 & 2.27 & 1.14 & .43 & $12.28^{* *}$ \\
\hline Grade 7 & 777 & 1.85 & 1.17 & 777 & 2.27 & 1.18 & .42 & $8.41^{\star *}$ \\
\hline Grade 8 & 745 & 1.83 & 1.04 & 745 & 2.27 & 1.11 & .44 & $8.97^{\star *}$ \\
\hline
\end{tabular}

Note: $* \mathrm{p}<.05, * * \mathrm{p}<.001$ 
Example responses by levels of student gain. The following student responses demonstrate levels of gains students made through the school year. These were chosen for the purpose of illustrating the levels of engineering conceptual growth (Table 6).

Table 6.

The levels of engineering conceptual growth.

\begin{tabular}{|c|c|c|c|c|}
\hline Growth (pre/post) & Prior to Program & Level & After Program & Level \\
\hline 0 Points & Fix things. & 2 & They work on stuff like cars. & 2 \\
\hline 1 Point & Building stuff. & 2 & $\begin{array}{l}\text { An engineer is a person who fixes things, like cars, } \\
\text { houses, and other things. }\end{array}$ & 3 \\
\hline 2 Points & They build stuff. & 2 & $\begin{array}{l}\text { An engineer solves problems by using math and sci- } \\
\text { ence. }\end{array}$ & 4 \\
\hline 3 Points & I don't know. & 0 & $\begin{array}{l}\text { I think engineers problem solve and think outside the } \\
\text { box. }\end{array}$ & 3 \\
\hline 4 Points & Do not know. & 0 & $\begin{array}{l}\text { There are many types of engineers, but an aerospace } \\
\text { engineer uses simulations to decide what will happen } \\
\text { and what could happen and then tries to make designs } \\
\text { to improve what [is] not working to its full potential. }\end{array}$ & 4 \\
\hline
\end{tabular}

Gains in Conceptions of Engineering by Student Gender

When disaggregated by gender, significant gains in conceptions of engineering were reported for both female students $(\mathrm{t}[770]=9.21, \mathrm{p}<.001)$ and male students $(\mathrm{t}[732]=7.92, \mathrm{p}<.001)$ (Table 7). Note that after one year in the program, males had a higher mean conceptions of engineering $(\mathrm{x} \bigotimes=2.34)$, but females reported an overall higher mean gain ( $\mathrm{m}$ difference of +.08 ).

Table 7.

Gains in Conceptions of engineering by Student Gender

\begin{tabular}{|c|c|c|c|c|c|c|c|c|}
\hline & \multicolumn{3}{|c|}{ Prior to Program } & \multicolumn{3}{|c|}{ After Program } & \multirow[b]{2}{*}{ Mean Gain } & \multirow[b]{2}{*}{$t$} \\
\hline & $n$ & $M$ & $S D$ & $n$ & $M$ & $S D$ & & \\
\hline Females & 771 & 1.73 & 1.12 & 771 & 2.20 & 1.15 & .47 & $9.21 * *$ \\
\hline Males & 733 & 1.95 & 1.09 & 733 & 2.34 & 1.13 & .39 & $7.92 * *$ \\
\hline
\end{tabular}

Note. $* \mathrm{p}<.05, * * \mathrm{p}<.001$

Differences between male and female levels of conceptions of engineering were significant prior to the program $(\bar{X}=1.95,1.73$, respectively), $\mathrm{t}(1502)=3.89, \mathrm{p}<.05$, but not after the program $(\bar{X}=2.34$, 2.20 , respectively), $\mathrm{t}(1502)=2.31, \mathrm{p}=.32$. There were no significant differences in gains between males and females, $\mathrm{t}(1502)=1.20, \mathrm{p}=.23$. While females tended to make slightly greater gains than males in conceptions of engineering ( $\mathrm{m}=.47, .39$, respectively), students' growth was comparable, regardless of gender. Perhaps the slight difference in growth $(\mathrm{m}=.08)$ was enough to begin to close the gap that existed between the levels of the two genders before their involvement in the program.

\section{Effect of Student-Fellow Engagement and Satisfaction}

The post-survey contained five items that asked students to rate their engagement and satisfaction with their Fellow. Students rated their level of agreement (on a scale of 1-5) with the following: (1) I like talking to our Fellow, (2) Our Fellow makes learning more interesting, (3) I like having a Fellow in our classroom, (4) I am more interested in studying science because we had a Fellow in our classroom, and (5) Our Fellow helps me understand what we're learning in class. 
The items were coded as a response or non-response according to the level each student selected on the five-point, Likert-type items. For example, all students who circled a two, or Disagree, for an item were coded as a response on that variable; any other selection was coded as a non-response. This created five variables for each item, corresponding to the students' selections. An independent samples t-test was run at each level to analyze the significance of growth in conceptions of engineering according to how students responded.

The higher level of agreement students selected on the engagement and satisfaction items, the more they correspondingly gained in their conceptions of engineering. Table 8 lists the gains in conceptions of engineering from the beginning to end of the program according to how students responded to the five-point, Likert-type items. These data show that students who were more engaged and satisfied with their GK-12 Fellow (indicated by a neutral response, agreed, or strongly agreed) had significant growth in their conceptions of engineering; those who were not engaged and satisfied with their Fellows (strongly disagreed or disagreed with the items) generally did not.

Table 8.

Mean Gains in Conceptions of Engineering by Fellow Engagement / Satisfaction

\begin{tabular}{|c|c|c|c|c|c|}
\hline Item & $\begin{array}{l}\text { Strongly } \\
\text { Disagree }\end{array}$ & Disagree & $\begin{array}{c}\text { Neither Agree } \\
\text { nor Disagree }\end{array}$ & Agree & $\begin{array}{l}\text { Strongly } \\
\text { Agree }\end{array}$ \\
\hline I like talking to our Fellow & .20 & .23 & $.41 * *$ & $.43^{* *}$ & $.53 * *$ \\
\hline $\begin{array}{l}\text { Our Fellow makes learning } \\
\text { more interesting }\end{array}$ & -.02 & .08 & $.33 * *$ & $.50 * *$ & $.51 * *$ \\
\hline $\begin{array}{l}\text { I like having a Fellow in our } \\
\text { classroom }\end{array}$ & .07 & .10 & $.26^{*}$ & $.44^{* *}$ & $.55^{* *}$ \\
\hline $\begin{array}{l}\text { I am more interested in study- } \\
\text { ing science because we had a } \\
\text { Fellow in our classroom }\end{array}$ & .21 & $.26^{*}$ & $.40^{* *}$ & $.49 * *$ & $.61 * *$ \\
\hline $\begin{array}{l}\text { Our Fellow helps me under- } \\
\text { stand what we're learning in } \\
\text { class }\end{array}$ & .11 & $.46^{* *}$ & $.26^{*}$ & $.45^{* *}$ & $.52 * *$ \\
\hline
\end{tabular}

Note. $* \mathrm{p}<.05, * * \mathrm{p}<.001$

\section{Students Involved for Two Years}

Some students were involved in GK-12 for a second year, either as 8th or 9th graders $(n=220)$. They completed pre- and post-surveys for both years, so their conception of engineering was analyzed to determine significance of means across both years of participation. The first year mean growth of the subset of students with a second year $(\mathrm{n}=220, \mathrm{~m}$ gain $=.37)$ and the remaining students with only one year $(\mathrm{n}=1302, \mathrm{~m}$ gain $=.44$ ) was not significantly different $\mathrm{t}(1520)=.749, \mathrm{p}=.454$. A repeated measures ANOVA was conducted to determine if means differed significantly during three time periods - prior to the program, after the first year, and after the second year. There were no significant outliers in the data, and the dependent variables were normally distributed when tested with the Shapiro-Wilk test of normality (pre $=.079$, post $=.164$ ). Mauchly's Test of Sphericity indicated that the assumption of sphericity had not been violated, $\chi 2(5)=5.18, p=.976$. No significant gains occurred between the end of the first year and the beginning of the second year $(M=2.10, S D$ $=1.16, \mathrm{p}=.25)$, so the second year pre-survey results were not included in this analysis.

The repeated measures ANOVA revealed means differed significantly between the three tested points $(\mathrm{F}[2,438]=35.32, \mathrm{p}<0.001)($ Table 9). Post hoc tests using the Bonferroni correction showed that the mean differences of students' conceptions of engineering prior to the program to the end of the first year $(\mathrm{M}=1.91$, $\mathrm{SD}=1.19 ; \mathrm{M}=2.27, \mathrm{SD}=1.18$, respectively) were significantly different $(\mathrm{p}<.001)$. Additionally, means after their second year of GK-12 involvement increased to $2.68(\mathrm{SD}=1.17)$, which was significantly greater than their conceptions of engineering both prior to the program $(\mathrm{p}<.001)$ and after the first year $(\mathrm{p}<.001)$. There was a 
statistically significant increase in students' conceptions of engineering after one year of GK-12 involvement, and an even greater and statistically significant increase after the second year of involvement.

Table 9.

Gains in Conceptions of Engineering, Two Years of Involvement

\begin{tabular}{|c|c|c|c|c|c|c|c|c|c|c|c|c|c|c|}
\hline & \multicolumn{3}{|c|}{ Prior to Program } & \multicolumn{3}{|c|}{ After Year 1} & \multicolumn{3}{|c|}{ After Year 2} & \multirow[b]{2}{*}{$\begin{array}{l}\text { Diff. } \\
\text { pre- } \\
\text { post }_{1}\end{array}$} & \multirow[b]{2}{*}{$\begin{array}{l}\text { Diff. } \\
\text { pre- } \\
\text { post }_{2}\end{array}$} & \multirow[b]{2}{*}{$F$} & \multirow[b]{2}{*}{$d f$} & \multirow[b]{2}{*}{$p$} \\
\hline & $n$ & $M$ & $S D$ & $n$ & $M$ & $S D$ & $n$ & $M$ & $S D$ & & & & & \\
\hline Total & 220 & 1.91 & 1.19 & 220 & 2.27 & 1.18 & 220 & 2.68 & 1.17 & .36 & .77 & 35.32 & 438 & $<.001$ \\
\hline Females & 121 & 1.70 & 1.19 & 121 & 2.12 & 1.20 & 121 & 2.66 & 1.18 & .42 & .96 & 28.29 & 240 & $<.001$ \\
\hline Males & 98 & 2.13 & 1.34 & 98 & 2.46 & 1.14 & 98 & 2.68 & 1.16 & .33 & .55 & 8.85 & 194 & $<.001$ \\
\hline
\end{tabular}

Note: Diff. pre-post1 is the difference between means prior to the program and after the first year.

Diff. pre-post2 is the difference between means prior to the program and after the second year.

When analyzed by gender, the female mean scores differed significantly between their conceptions of engineering prior to the program, after the first year, and after the second year $(F[2,240]=28.29, \mathrm{p}<0.001)$. Mean differences of female students' conceptions of engineering from these three points were statistically significant $(\mathrm{p}<.001)$. Male students' scores also differed significantly during the three time periods $(\mathrm{F}[2,194]$ $=8.85, \mathrm{p}<0.001)$.

From prior involvement in the program (female $\bar{X}=1.70, \mathrm{SD}=1.19$; male $\bar{X}=2.13, \mathrm{SD}=1.34$ ) to the end of their second year of involvement (female $\bar{X}=2.66, \mathrm{SD}=1.18$; male $\bar{X}=2.68, \mathrm{SD}=1.16$ ), males had a mean growth of .55 in their conceptions of engineering, while females' mean growth was almost twice as much at .96. The scores prior to the program were significantly different, with the females' means lower than the males' ( $\bar{X}=1.70,2.13$, respectively), $\mathrm{t}(217)=2.72, \mathrm{p}=.007$. By the end of two years of involvement, the growth females made in conceptions of engineering allowed them to catch up completely to males $(\bar{X}=2.66$, 2.68 , respectively), $\mathrm{t}(217)=.14, \mathrm{p}=.965$ (see Figure 1$)$.

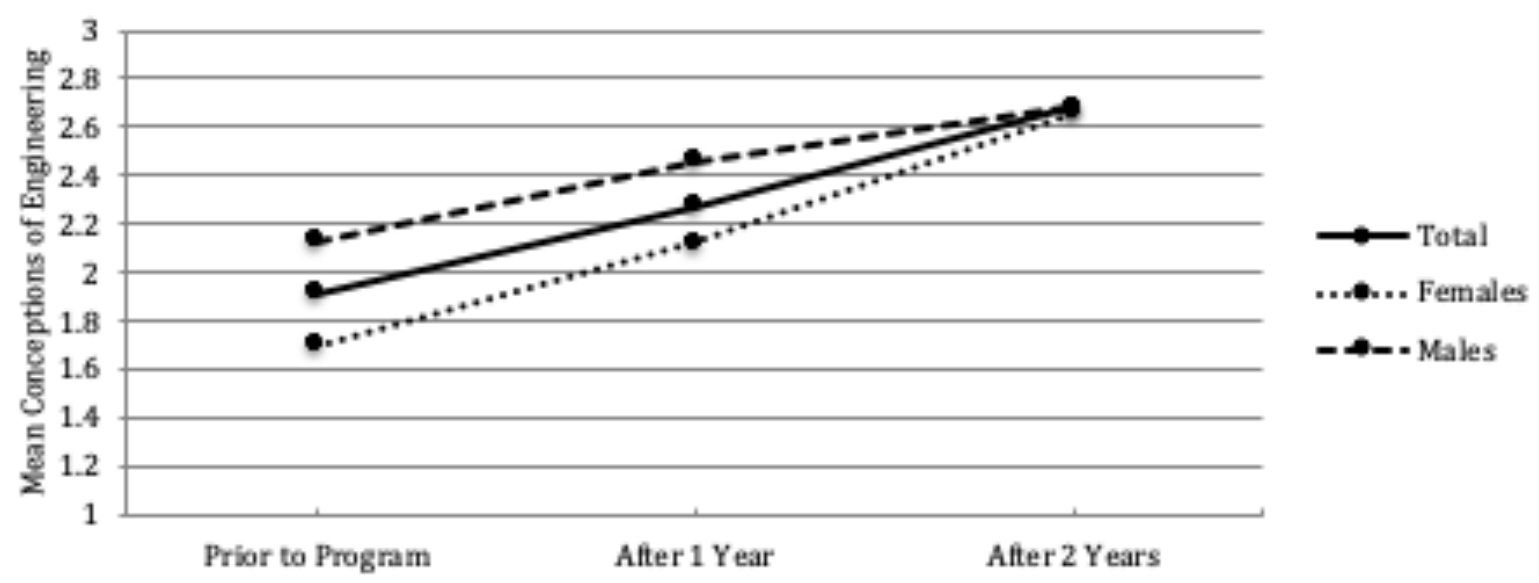

Figure 1. Mean level of students involved a second year at three measured points 


\section{Discussion}

Overall, students who had a Fellow in their classrooms developed a significantly higher level of conceptions of engineering from beginning of the school year to the end, regardless of the gender of the student, or the gender or program of study of the Fellow. Like other middle school STEM career conception research (Knezek et al., 2013), this study found that in a single year, female students made slightly, but not significantly, greater gains than males (female $\mathrm{M}=.45$, male $\mathrm{M}=.38$ ). Although females grew marginally more than males in their conceptions of engineering, they typically started and ended at a lower level.

Still, a gap still existed in how males and females conceptualize the field. In the second year of involvement, though, females were making greater strides in their conceptions of engineering gains $(\mathrm{M}=.72)$. Overall, students who had a Fellow for a second year started and ended at a higher level than those involved for only one year, suggesting the second year may have played a greater role in students' development of understanding about the engineering field, and females may benefit even more from having a second year in these types of programs. This confirms prior research that indicates middle school engineering programs may have a greater impact on females' gains in conceptions of engineering (Christensen \& Knezek, 2017).

Additionally, the more students were engaged and satisfied with their Fellows, the greater gains they made in their conceptions of engineering. It may be explained that students who ranked the "I like talking to our Fellow" item higher were more likely to have spent time conversing with their Fellows during class, asking their Fellows questions during class time, and staying after class to have conversations with their Fellows about science or their potential careers. This could partially explain why those who ranked this item higher made greater gains in their conceptions of engineering.

It can also be concluded that those students enjoyed having a Fellow in their classroom, enjoyed the presence of their particular Fellow, and felt it was motivating and academically beneficial to have one teaching them. Recent related research found that middle school students in authentic, project-based scientist partnership classrooms demonstrated significantly greater levels of positive attitudes, engagement, and confidence in science than their peers (Basche, Genareo, Leshem, Kissel, \& Pauley, 2016). Teaching middle school students effectively requires much more than content and pedagogy; it is vital that teachers form relationships with students, make the students feel safe and secure, model caring and support, and tend to their personal and social development (Kellough \& Kellough, 1999). Students in this study may have had more positive attitudes prior to, or because of, the GK-12 program itself, or had a Fellow who was a more effective communicator or teacher.

In similar research of African American students, Thompson and Lyons (2008) found that "six out of the ten experimental group students interviewed attributed some aspect of their engineering perceptions to previous involvement with a Fellow" (p. 201). In their study, however, all of the Fellows were engineering students. It should be noted that during four years of the GK-12 program, Fellows in engineering fields taught only eight out of the 34 classes, and yet students still made gains in conceptions of engineering across the board. This may be due to the symbiotic relationship and shared traits of engineering and science fields (Dugger, 1993), so having science Fellows still could have contributed to students' gains in conceptions of engineering.

One limitation of this study is that there is not enough information about the particular pedagogical contexts to explain differences. Whether or not an activity was presented from a standpoint of an engineer or a scientist may have affected how students understood engineering. It is also a limitation that the open-ended response was written, meaning literacy and writing skills could have affected the depth of student responses. Improved writing skills, or even increased motivation over the course of the school year, may have slightly affected the generally improved conceptions of engineering by the end of the year. Finally, there was no control group. Simply, putting the program into practice and working with real, research-consenting students made a control group infeasible. Consequently, it is difficult to claim that the GK-12 program was definitively responsible for students' gains in conceptions of engineering, although the effects of Fellow engagement and satisfaction on their conceptual growth were promising and supportive findings. Still, this study adds to the ever-growing 
body of research suggesting STEM partnership programs likely positively affect students' understanding of engineering and STEM fields (Lyons, 2011; Thompson \& Lyons, 2008). Future research should examine these findings with a control group to isolate variables that may be affecting middle school conceptions of engineering.

Results of this study reinforce the call for science enrichment programs (McBride, Brewer, Bricker, \& Machura, 2011). Since the GK-12 program has been phased out as an NSF initiative, schools and universities must continue to partner to provide authentic STEM experiences to schoolteachers and students. Not only are these experiences beneficial for graduate students (George \& Tankersley, 2013) and teachers (Lyons, Thompson, \& Addison, 2007), but they also appear to help students develop higher-level understanding of the engineering fields, particularly for students involved more than one year.

The Next Generation Science Standards were revised in part to ensure that concepts of engineering were being addressed in all schools, because "engineering wasn't in most states... a child could go through K-12 school without finding out what an engineer does" (Cardno, 2013, p. 26). Although a majority of predicted job growth in the United States is in STEM areas, there is still far more demand than supply in the job market, particularly among females in STEM fields (Dasgupta \& Stout, 2014). Focused STEM intervention programs are of national importance because they can introduce K-12 students to careers in STEM and help grow the future job force (Shoffner \& Dockery, 2015), and this study showed that the GK-12 program contributed to this by helping middle school students better understand engineering careers.

\section{Conclusions and Implications}

The purpose of this study was to investigate students' conceptions of engineering at the beginning and end of a year of a school-university STEM partnership program. Results suggested that this program may have been effective in helping students develop more sophisticated levels of understanding of engineering and alleviate some misconceptions about the engineering field. However, students' growth in conceptions of engineering was largely dependent on their level of engagement and satisfaction with their university Fellows. Some promising research in engineering-based, middle school summer camps supports our findings that effective, teacher and engineer partnership models can provide measurable effects on students' understanding of engineering (Hammack, Ivey, Utley, \& High, 2015).

The next direction of research in this area should examine types of interactions that take place in the middle school classroom in an attempt to clarify how growth in conception of STEM fields is supported through student and Fellow relationship. Future researchers can also use and test the coding rubric developed in this study in conceptions of engineering surveys and further refine it, if needed, to establish a valid and reliable tool for examining students' responses. If confirmed to be effective, the process of using a single, open-ended item and scoring rubric could serve a different, and potentially more efficient, way to assess a large number of students' conceptions of engineering than the Draw-an-Engineer Test. Additionally, the researchers developed a system of categorizing engineering products and engineering gender from students' written responses to the item. This was not reported in the present study, but is available upon author request.

This research was unique because it looked not only at conceptual growth, but found some evidence that students' attitudes about the Fellows played a role in how much they learned about the engineering field. These, and other research results, offer encouraging evidence for the importance of similar programs in middle schools (Barrett, Moran, \& Woods, 2014; Blanchard et al., 2015). To develop the future STEM workforce, schools must provide students the opportunities to learn about the careers and develop interest in them during the critical middle-level years or earlier, particularly if a goal to develop females' STEM career interest (Christensen \& Knezek, 2017).

These findings also give some insight into the value of ensuring graduate students in middle school STEM intervention programs understand developmentally appropriate teaching strategies. Students at this age are more likely to be motivated to learn by teachers who care about their students, although this level of 
teacher warmth often declines during the middle school years (Hughes \& Cao, 2018). Middle school students tend to respond better to teachers who are positive and constructive, and with whom they feel comfortable talking. Effective teachers tend not only to students' academic needs, but also to their social-emotional needs (Stronge, 2018). Those responsible for placing university Fellows in classrooms should choose and develop graduate students who not only have content and pedagogical knowledge, but also are personable and caring. Their interactions with students may play a larger role in developing middle school students' STEM career conceptions than previously known.

\section{References}

Banerjee, A. (2015). Women's enrollment in engineering is growing. Databytes, Prism, American Society for Engineering Education. Retrieved from http://www.asee-prism.org/databytes-sep/.

Barrett, B. S., Moran, A. L., \& Woods, J. E. (2014). Meteorology meets engineering: an interdisciplinary STEM module for middle and early secondary school students. International Journal of STEM Education, 1(1), 6.

Basche, A., Genareo, V., Leshem, A., Kissell, A., \& Pauley, J. (2016). Engaging middle school students through locally-focused environmental science project-based learning. Natural Sciences Education, 45(1). doi: 10.4195/nse2016.05.0012.

Blanchard, S., Judy, J., Muller, C., Crawford, R. H., Petrosino, A. J., White, C. K., Lin, F., \& Wood, K. L. (2015). Beyond blackboards: Engaging underserved middle school students in engineering. Journal of Pre-College Engineering Education Research, 5(1).

Cantrell, P., \& Robinson, M. (2002). How do 4th through 12th grade science textbooks address applications in engineering and technology? Bulletin of Science, Technology \& Society, 22(1), 31-41.

Capobianco, B. M., Diefes-Dux, H. A., Mena, I., \& Weller, J. (2011). What is an engineer? Implications of elementary school student conceptions for engineering education. Journal of Engineering Education, $100(2), 304-328$.

Cardno, C. A. (2013). New K-12 science, engineering standards unveiled. Civil Engineering - American Society of Civil Engineers, 83(6), 26-27.

Chambers, D. (1983). Stereotype images of the scientists: The Draw-a-Scientist Test. Science Education, 67, 255-265.

Christensen, R., \& Knezek, G. (2017). Relationship of middle school student STEM interest to career intent. Journal of Education in Science, Environment and Health, 3(1), 1-13.

Cunningham, C. M., Lachapelle, C. P., \& Lindgren-Streicher, A. (2005, June). Assessing elementary school students' conceptions of engineering and technology. Paper in the proceedings of the 2005 American Society for Engineering Education Annual Conference \& Exposition.

Dasgupta, N., \& Stout, J. G. (2014). Girls and women in science, technology, engineering, and mathematics STEMing the tide and broadening participation in STEM careers. Policy Insights from the Behavioral and Brain Sciences, 1(1), 21-29.

Davis, L. A., \& Gibbons, R. D. (2002). Raising public awareness of engineering. Washington, DC: The National Academies Press.

DeGrazia, J. L., Sullivan, J. F., Carlson, L. E., \& Carlson, D. W. (2001). AK-12/University partnership: Creating tomorrow's engineers. Journal of Engineering Education, 90(4), 557-563.

Dugger, W. E. (1993). The relationship between technology, science, engineering, and mathematics. Paper in the proceedings of the Annual Conference of the American Vocational Association (Nashville, TN, December 3-7, 1993)

Eide, A. R., Jenison, R. D., Northup, L. L., \& Mickelson, S. K. (2012). Engineering fundamentals and problem solving (6th ed.). New York, NY: McGraw Hill. 
Finson, K. D. (2002). Drawing a scientist: What we do and do not know after fifty years of drawings. School Science and Mathematics, 102(7), 335-345.

Fralick, B., Kearn, J., Thompson, S., \& Lyons, J. (2009). How middle schoolers draw engineers and scientists. Journal of Science Education and Technology, 18(1), 60-73.

Genareo, V. R., Mitchell, J., Geisinger, B., \& Kemis, M. (2016). University science partnerships: What happens to STEM interest and confidence in middle school and beyond? K-12 STEM Education, 2(4), 117-127.

George, M., \& Tankersley, R. (2013). Evidence of success of the GK-12 approach. In T. Spuck, K. Stoll, \& S. Ortega, (Eds.), The power of partnerships: A guide from the NSF Graduate STEM Fellows in K-12 in Education (GK-12) program (pp. 119-128). American Association for the Advancement of Science.

Gilbert, G. E., \& Prion, S. (2016). Making sense of methods and measurement: Lawshe's Content Validity Index. Clinical Simulation in Nursing, 12(12), 530-531

Hammack, R., \& High, K. (2014). Effects of an after school engineering mentoring program on middle school girls' perceptions of engineers. Journal of Women and Minorities in Science and Engineering, 20(1), 11-20.

Hammack, R., Ivey, T. A., Utley, J., \& High, K. A. (2015). Effect of an engineering camp on students' perceptions of engineering and technology. Journal of Pre-College Engineering Education Research (J-PEER), 5(2), 2.

Hirsch, L. S., Carpinelli, J. D., Kimmel, H., Rockland, R. \& Bloom, J. (2007). The differential effects of preengineering curricula on middle school students' attitudes to and knowledge of engineering careers. Paper in the proceedings of the 37th ASEE/IEEE Frontiers in Education Conference, Milwaukee, WI.

Hughes, J. N., \& Cao, Q. (2018). Trajectories of teacher-student warmth and conflict at the transition to middle school: Effects on academic engagement and achievement. Journal of School Psychology, 67, 148-162.

Kelley, M. S., \& Bryan, K. K. (2018). Gendered perceptions of typical engineers across specialties for engineering majors. Gender and Education, 30(1), 22-44.

Kellough, R. D., \& Kellough, N. G. (1999). Middle school teaching: A guide to methods and resources. Upper Saddle River, NJ: Merrill Publishing.

Knezek, G., Christensen, R., Tyler-Wood, T., \& Periathiruvadi, S. (2013). Impact of environmental power monitoring activities on middle school student perceptions of STEM. Science Education International, 24(1), 98-123.

Knight, M., \& Cunningham, C. M. (2004) Draw an Engineer Test (DAET): Development of a tool to investigate students' ideas about engineers and engineering. Paper in the proceedings of The American Society of Engineering Education Annual Conference \& Exposition, Salt Lake City, UT.

Komarraju, M., Swanson, J., \& Nadler, D. (2014). Increased career self-efficacy predicts college students' motivation, and course and major satisfaction. Journal of Career Assessment, 22(3), 420-432.

Landis, J. R., \& Koch, G. G. (1977). The measurement of observer agreement for categorical data. Biometrics, $33,159-174$.

Leedy, P. (1997). Practical research: Planning and design. Upper Saddle River, NJ: Prentice-Hall, Inc.

Lent, R. W., Brown, S. D., \& Hackett, G. (2002). Social cognitive career theory. Career Choice and Development, 4, 255-311.

Lyons, J. S. (2011). AC 2011-161: GK-12 engineering fellows change student perceptions; Science fellows, not so much. Paper presented at the 2011 American Society for Engineering Education, 1-18. Retrieved from: https://www.asee.org/public/conferences/1/papers/161/view

Lyons, J., Thompson, S., and Addison, V. (2007). GK-12 engineering workshop for science and math teachers. Paper in the proceedings of the 2007 ASEE Annual Conference and Exposition, Honolulu, Hawaii.

McBride, B. B., Brewer, C. A., Bricker, M., \& Machura, M. (2011). Training the next generation of renaissance scientists: The GK-12 ecologists, educators, and schools program at the University of Montana. Bioscience, 
61(6), 466-476.

McDuffie Jr., T. E. (2001). Scientists - Geeks and nerds. Science and Children, 38(8), 16-19.

Mitchell, J., Levine, R., Gonzalez, R., Bitter, C., Webb, N., \& White, P. (2003). Evaluation of the National Science Foundation Graduate Teaching Fellows in K-12 Education (GK-12) Program. Paper presented at the Annual Meeting of the American Educational Research Association, Chicago, IL, April 21-25, 2003.

Mohr-Schroeder, M. J., Jackson, C., Miller, M., Walcott, B., Little, D. L., Speler, L., Schooler, W., \& Schroeder, D. C. (2014). Developing middle school students' interests in STEM via summer learning experiences: See Blue STEM Camp. School Science and Mathematics, 114(6), 291-301.

National Academy of Engineering. (2008). Changing the conversation: Messages for improving public understanding of engineering. Washington, DC: National Academies Press.

Oware, E., Capobianco, B., \& Diefes-Dux, H. A. (2007). Young children's perceptions of engineers before and after a summer engineering outreach course. In Frontiers In Education Conference - Global Engineering: Knowledge Without Borders, Opportunities Without Passports. 37th Annual ASEE/IEEE, S2B-3 - S2B-8.

Page, C. A., Lewis, C. W., Autenrieth, R. L., \& Butler-Purry, K. L. (2013). Enrichment experiences in engineering (E3) for teachers' summer research program: An examination of mixed-method evaluation findings on high school teacher implementation of engineering content in high school STEM classrooms. Journal of STEM Education: Innovations \& Research, 14(3), 27-33.

Rockland, R., Bloom, D. S., Carpinelli, J., Burr-Alexander, L., Hirsch, L. S., \& Kimmel, H. (2010). Advancing the "E" in K-12 STEM education. Journal of Technology Studies, 36(1), 53-64.

Shoffner, M. F., \& Dockery, D. J. (2015). Promoting interest in and entry into science, technology, engineering, and mathematics careers. In P. J. Hartung, M. L. Savickas, \& Walsh, B. W. (Eds.). APA handbook of career intervention, Volume 2: Applications. APA handbooks in psychology (pp. 125-137). Washington, DC: American Psychological Association.

Stronge, J. H. (2018). Qualities of effective teachers. Alexandria, VA: ASCD.

Tafoya, J., Nguyen, Q., Skokan, C., \& Moskal, B. (2005). K-12 outreach in an engineering intensive university. Paper in the proceedings of the 4th ASEE/AaeE Global Colloquium on Engineering Education, Australasian Association of Engineering Education.

Thompson, S., \& Lyons, J. (2008). Engineers in the classroom: Their influence on African-American students' perceptions of engineering. School Science and Mathematics, 108(5), 197-211.

Tonso, K. L. (2006). Student engineers and engineer identity: Campus engineer identities as figured world. Cultural Studies of Science Education, 1(2), 237-307.

Vosniadou, S. (1994). Capturing and modeling the process of conceptual change. Learning and Instruction, $4(1), 45-69$.

Vosniadou, S. (2007). Conceptual change and education. Human Development, 50(1), 47-54.

Vosniadou, S., Ioannides, C., Dimitrakopoulou, A., \& Papademetriou, E. (2001). Designing learning environments to promote conceptual change in science. Learning and Instruction, 11(4), 381-419.

Yap C., Ebert C., \& Lyons J. (2003) Assessing students' perception of the engineering profession. Paper presented at the South Carolina educators for the practical use of research annual conference, Columbia SC, February 28, 2003.

Yoder, B. L. (2014). Engineering by the numbers 2013-2014. American Society for Engineering Education, retrieved from: https://www.asee.org/papers-and-publications/publications/14_11-47.pdf 


\section{Appendix A. Response coding rubric}

\begin{tabular}{|c|c|c|}
\hline Code & Rule & Examples \\
\hline 0 & $\begin{array}{l}\text { Student response had nothing to do with the question } \\
\text { asked. }\end{array}$ & I don't know. \\
\hline 1 & $\begin{array}{l}\text { 1) Response displays significant misconceptions about } \\
\text { engineers } \\
\text { 2) Or, response equates engineers to mechanies or } \\
\text { train workers/operators (Knight \& Cunningham, } \\
\text { 2004) }\end{array}$ & $\begin{array}{l}\text { 1) Engineers work in hospitals taking care of } \\
\text { the sick } \\
\text { 2) Fixes car motors } \\
\text { 2) Works on cars or trains }\end{array}$ \\
\hline 2 & $\begin{array}{l}\text { 1) Response shows a vague understanding of } \\
\text { engineering but uses very abstract deseriptions that } \\
\text { could apply to other disciplines besides just } \\
\text { engineering } \\
\text { 2) Or, response includes variations of BUILDS, } \\
\text { MAKES, or FIXES. (Fralick et al., 2009) } \\
\text { 3) Or, provides a concrete product example }\end{array}$ & $\begin{array}{l}\text { 1) Electricity } \\
\text { 1) Uses science and math } \\
\text { 2) Builds things } \\
\text { 2) Builds cars and computers } \\
\text { 2) Works on cars and electronics } \\
\text { 2) Construction } \\
\text { 3) Makes things like computers }\end{array}$ \\
\hline 3 & $\begin{array}{l}\text { 1) Response describes one function of an engineer, such } \\
\text { as problem solving, researching, developing, } \\
\text { designing, testing, operations, sales, consulting, } \\
\text { teaching (Eide et al., 2012) managing, or } \\
\text { evaluating (Landis, 2007), improve } \\
\text { 2) Provides more than one conerete example }\end{array}$ & $\begin{array}{l}\text { 1) Designs things } \\
\text { 1) Inventing things } \\
\text { 1) Crestes or invents things } \\
\text { 1) Problem-solvers } \\
\text { 1) Tests cars, computers, etc. } \\
\text { 1) They do lots of things like teaching } \\
\text { 2) Makes things like compaters, cars } \\
\text { bridges... }\end{array}$ \\
\hline \multirow{3}{*}{4} & $\begin{array}{l}\text { 1) Response includes multiple functions of engineers, } \\
\text { as described in "code 3" (Eide et al., 2012; Landis, } \\
\text { 2007) }\end{array}$ & $\begin{array}{l}\text { 1) Engineers researeh and design computers, } \\
\text { buildings } \\
\text { 1) Designs, makes and fixes electronic and } \\
\text { mechanical equipment } \\
\text { 1) Work in different areas like testing. } \\
\text { production, and maintenance }\end{array}$ \\
\hline & $\begin{array}{l}\text { 2) Or, response includes an example of engineering and } \\
\text { states that they help improve soeiety or their } \\
\text { organization (Eide et al., 2012; Landis, 2007) }\end{array}$ & $\begin{array}{l}\text { 2) Engineers design things in medical fields } \\
\text { that help people and doctors } \\
\text { 2) Help society by inventing things people } \\
\text { need and use. } \\
\text { 2) Help companies they work for make } \$ \text { by } \\
\text { designing things they need }\end{array}$ \\
\hline & $\begin{array}{l}\text { 3) Or, response includes codes } 2 \text { and } 3 \text { together } \\
\text { (Landis, 2007) }\end{array}$ & $\begin{array}{l}\text { 3) Use problem solving to build cars, } \\
\text { computers, ete. } \\
\text { 3) Use science and math to design medical } \\
\text { instruments, bridges... }\end{array}$ \\
\hline
\end{tabular}

